\title{
Natural DENV-2 NS2B/NS3 protease inhibitors from Myristica cinnamomea King
}

\author{
Sivasothy, Y. ${ }^{1}$, Liew, S.Y. ${ }^{2}$, Othman, M.A. ${ }^{3}$, Abdul Wahab, S.M. ${ }^{4}$, Hariono, M. ${ }^{5}$, Mohd Nawi, M.S. ${ }^{6}$, \\ Abdul Wahab, H.7, Awang, K. ${ }^{3,8^{*}}$ \\ ${ }^{1}$ School of Pharmacy, Monash University Malaysia, 47500 Bandar Sunway, Selangor, Malaysia \\ ${ }^{2}$ Chemistry Division, Centre for Foundation Studies in Science, Universiti Malaya, 50603 Kuala Lumpur, Malaysia \\ ${ }^{3}$ Department of Chemistry, Faculty of Science, Universiti Malaya, 50603 Kuala Lumpur, Malaysia \\ ${ }^{4}$ Drug and Herbal Research Centre, Faculty of Pharmacy, Universiti Kebangsaan Malaysia, 50300 Kuala Lumpur, Malaysia \\ ${ }^{5}$ Faculty of Pharmacy, Sanata Dharma University, Campus III, 55284 Yogyakarta, Indonesia \\ ${ }^{6}$ Department of Pharmaceutical Chemistry, Kulliyah of Pharmacy, International Islamic University Malaysia, 25200 Kuantan, Pahang, Malaysia \\ ${ }^{7}$ School of Pharmaceutical Sciences, Universiti Sains Malaysia, 11800 Minden, Penang, Malaysia \\ ${ }^{8}$ Centre for Natural Products and Drug Discovery (CENAR), Universiti Malaya, 50603 Kuala Lumpur, Malaysia \\ *Corresponding author: khalijah@um.edu.my
}

\section{ARTICLE HISTORY}

Received: 21 September 2020

Revised: 11 January 2021

Accepted: 12 January 2021

Published: 30 April 2021

\begin{abstract}
The NS2B/NS3 protease is crucial for the pathogenesis of the DENV. Therefore, the inhibition of this protease is considered to be the key strategy for the development of new antiviral drugs. In the present study, malabaricones C (3) and E (4), acylphenols from the fruits of Myristica cinnamomea King, have been respectively identified as moderate $(27.33 \pm 5.45 \mu \mathrm{M})$ and potent $(7.55 \pm 1.64 \mu \mathrm{M})$ DENV-2 NS2B/NS3 protease inhibitors, thus making this the first report on the DENV-2 NS2B/NS3 protease inhibitory activity of acylphenols. Based on the molecular docking studies, compounds 3 and $\mathbf{4}$ both have $\pi-\pi$ interactions with Tyr 161 . While compound 3 has hydrogen bonding interactions with Gly151, Gly153 and Tyr161, compound 4 however, forms hydrogen bonds with Ser135, Asp129, Phe130 and Ile86 instead. The results from the present study suggests that malabaricones $C(3)$ and $E(4)$ could be employed as lead compounds for the development of new dengue antivirals from natural origin.
\end{abstract}

Keywords: Myristica cinnamomea King; acylphenols; malacaricone C; malabaricone E; DENV-2 NS2B/NS3 protease.

\section{INTRODUCTION}

Dengue is a viral disease which leads to considerable morbidity and mortality (Balasubramanian et al., 2019; Dighe et al., 2019). The dengue virus (DENV), one of the most rapidly spreading mosquito-borne viral pathogens in the tropical and subtropical regions of the world, is a member of the genus Flavivirus (family Flaviviridae). The DENV is transmitted to humans via the bite of infected Aedes aegypti and Aedes albopictus mosquitos. This virus causes a wide spectrum of infections ranging from a non-severe form, the dengue fever (DF), to more severe forms such as dengue haemorrhagic fever (DHF) and dengue shock syndrome (DSS) (Mir et al., 2016; Weng et al., 2017; Perera et al., 2018; Balasubramanian et al., 2019; Rozera et al., 2019). There are five distinct, yet closely related, stereotypes of the DENV which include DENV1, DENV-2, DENV-3, DENV-4, DENV-5 with DENV-2 being the most prevalent among the five (de Sousa et al., 2015; Mir et al., 2016; Aguilera-Pesantes et al., 2017; Singh \& Rawat, 2017; Weng et al., 2017; Perera et al., 2018).
The NS2B/NS3 protease is a two component nonstructural protein in the genomic sequence of the DENV. This enzyme mediates the cleavage of polyproteins which subsequently releases functional proteins that are required for the production of mature DENV and for maintaining its infectivity. Hence, it can be concluded that the NS2B/NS3 protease plays an important role in the genome replication process of the DENV. The NS2B/NS3 protease is therefore an ideal target for drug discovery against dengue infection (de Sousa et al., 2015; Timiri et al., 2016; Aguilera-Pesantes et al., 2017; Takagi et al., 2017; Weng et al., 2017).

A large number of medicinal plants have been used to alleviate dengue infection. As a result, the secondary metabolites derived from these plants could be potential sources of dengue antiviral agents. To date, flavonoids, chalcones, biflavonoids, phenolics, alkaloids and curcuminoids have been reported to inhibit the DENV-2 NS2B/NS3 protease (Abd Kadir et al., 2013; Abubakr et al., 2013; Teixeira et al., 2014; de Sousa et al., 2015; Mir et al., 2016; Timiri et al., 2016; Singh \& Rawat, 2017; Perera et al., 2018; Balasubramanian et al., 2019; Dighe et al., 2019). 
In search of new small molecule scaffolds as lead compounds for the inhibition of the DENV-2 NS2B/NS3 protease, we decided to investigate the inhibiting potential of acylphenols. Herein, we report on the isolation of malabaricones A-C (1-3) and E (4) from the fruits of Myristica cinnamomea King (Figure 1). Their structures were characterized by means of NMR and MS spectral analyses. These acylphenols were subsequently evaluated for their DENV-2 NS2B/NS3 protease inhibitory activity. Following this, molecular docking was performed in order to provide insights into the binding interactions between the most promising acylphenol(s) and the DENV-2 NS2B/NS3 protease.

\section{MATERIALS AND METHODS}

\section{General experimental procedures}

Analytical and preparative TLC was carried out on Merck 60 $\mathrm{F}_{254}$ silica gel plates (absorbent thickness: 0.25 and $0.50 \mathrm{~mm}$, respectively) (Merck, Germany). Column chromatography (CC) was performed using silica gel (230-400 mesh, ASTM) (Merck, Germany) and Sephadex LH-20 (Sigma-Aldrich, USA). IR spectra were recorded using a Perkin-Elmer Spectrum 400 FT-IR Spectrometer. NMR spectra were acquired in $\mathrm{CD}_{3} \mathrm{OD}$ (Merck, Germany) using a JOEL ECA $400 \mathrm{MHz}$ NMR Spectrometer. LCMS-IT-TOF spectra were obtained using an Agilent 6530 Accurate-Mass Q-TOF LC/MS system. UV spectra were recorded using a Shimadzu 1650 PC UV-Vis Spectrophotometer. All solvents were of analytical grade and were distilled prior to use. DMSO and Tris- $\mathrm{HCl}$ buffer were respectively purchased from Merck (Germany) and Sigma-Aldrich (USA) while BocGly-Arg-Arg-MCA was purchased from Peptide Institute, Inc (Japan).

\section{Plant Material}

M. cinnamomea was collected from Johor in 2003. The plant was identified by Mr. Teo Leong Eng and a voucher specimen (KL 5043) has been deposited with the University of Malaya herbarium.

\section{Isolation and characterization of compounds 1-4}

Dried powdered fruits $(1.5 \mathrm{~kg})$ of $M$. cinnamomea were extracted with ethyl acetate $(5.0 \mathrm{~L}, 2 \mathrm{x})$ at room temperature, yielding $262.99 \mathrm{~g}$ of extract. The ethyl acetate extract $(30 \mathrm{~g})$ was chromatographed on a silica gel column $(625 \mathrm{~g}, 7.2 \mathrm{~cm} x$ $63 \mathrm{~cm}$ ). Elution was carried out using mixtures of dichloro- methane : acetone in proportions of 90:10 (v/v, $3 \mathrm{~L}), 85: 15$ $(\mathrm{v} / \mathrm{v}, 5 \mathrm{~L}), 80: 20(\mathrm{v} / \mathrm{v}, 5 \mathrm{~L})$ and $75: 25(\mathrm{v} / \mathrm{v}, 3 \mathrm{~L})$ sequentially to afford fractions FA $(5.73 \mathrm{~g}), \mathrm{FB}(2.44 \mathrm{~g}), \mathrm{FC}(8.50 \mathrm{~g})$ and FD $(6.25 \mathrm{~g})$, respectively. FA was fractionated on a silica gel column (180 g, $2.5 \mathrm{~cm} \times 72 \mathrm{~cm}$ ), eluted using dichloromethane $(2 \mathrm{~L})$ to afford sub-fraction FA 1 (3.24 g), following which FA 1 was re-chromatographed over a Sephadex LH-20 column $(25 \mathrm{~g})$ using methanol $(1 \mathrm{~L})$ as the eluent to afford 1 (2.70 g). FB was subjected to column chromatography over $60 \mathrm{~g}$ of silica gel $(2.5 \mathrm{~cm} \times 64.5 \mathrm{~cm})$ with an isocratic solvent system of dichloromethane : acetone $(95: 5 \mathrm{v} / \mathrm{v}, 1 \mathrm{~L})$ to provide subfraction FB 1 (1.86 g). FB 1 was further purified by passing it through a Sephadex LH-20 column ( $25 \mathrm{~g}$ ) with methanol (500 $\mathrm{mL}$ ) to yield $2(1.29 \mathrm{~g})$. Column chromatography of FC over silica gel $(270 \mathrm{~g}, 5.0 \mathrm{~cm} \times 72 \mathrm{~cm})$ to afford sub-fraction FC 1 $(6.50 \mathrm{~g})$ was achieved using dichloromethane : acetone (90:10 $\mathrm{v} / \mathrm{v}, 1 \mathrm{~L}$ ). Next, the purification of FC 1 to provide 3 (5.18 g) was carried out over a Sephadex LH-20 column (25 g) using methanol $(1 \mathrm{~L})$ as the eluting solvent. Column chromatography of FD over silica gel $(180 \mathrm{~g}, 2.5 \mathrm{~cm} \times 72 \mathrm{~cm})$ with successive elutions using dichloromethane : acetone in ratios of (85:15 $\mathrm{v} / \mathrm{v}, 300 \mathrm{~mL})$ and $(80: 20 \mathrm{v} / \mathrm{v}, 500 \mathrm{~mL})$ afforded sub-fractions FD $1(3.14 \mathrm{~g})$ and FD $2(1.25 \mathrm{~g})$, respectively. FD 1 was rechromatographed over a silica gel column $(120 \mathrm{~g}, 2.5 \mathrm{~cm} \times 72$ $\mathrm{cm})$ with an isocratic solvent system of dichloromethane : acetone $(80: 20 \mathrm{v} / \mathrm{v}, 1.5 \mathrm{~L})$ to give sub-fractions FD $1.1(0.09 \mathrm{~g})$, FD $1.2(0.08 \mathrm{~g})$ and FD 1.3 (1.05 g). FD 1.2 was purified over a Sephadex LH-20 column ( $25 \mathrm{~g})$ using methanol $(500 \mathrm{~mL})$ as the eluent to afford sub-fraction FD 1.2.1 (0.02 g) which was later purified via repetitive preparative TLC with dichloromethane : acetone [75:25 v/v] to yield $4(4.6 \mathrm{mg})$. The degree of the purity of the isolated compounds was determined by ${ }^{1} \mathrm{H}$ NMR spectroscopy and was found to be $98 \%-99 \%$ pure.

\section{Malabaricone A (1)}

Pale yellow amorphous powder. UV (MeOH): 342 (3.07), 269 (3.67), 214 (3.78). IR ( $\mathrm{NaCl}): 3583,3271,2920,2851,1714,1589$, 1511. ${ }^{1} \mathrm{H}-\mathrm{NMR}\left(\mathrm{CD}_{3} \mathrm{OD}, 400 \mathrm{MHz}\right): 7.23(2 \mathrm{H}, \mathrm{m}, \mathrm{H}-12$ \& H-14), 7.21 $(1 \mathrm{H}, \mathrm{t}, J=8.0, \mathrm{H}-19), 7.17(2 \mathrm{H}, \mathrm{m}, \mathrm{H}-11$ \& $\mathrm{H}-15), 7.12(1 \mathrm{H}, \mathrm{m}, \mathrm{H}-13)$, $6.34(2 \mathrm{H}, \mathrm{d}, J=8.0, \mathrm{H}-18 \& \mathrm{H}-20), 3.10(2 \mathrm{H}, \mathrm{t}, J=8.0, \mathrm{H}-2), 2.58(2 \mathrm{H}$, $\mathrm{t}, J=8.0, \mathrm{H}-9), 1.66(2 \mathrm{H}, \mathrm{brt}, J=8.0, \mathrm{H}-3), 1.58(2 \mathrm{H}, \mathrm{brt}, J=8.0, \mathrm{H}-$ 8), 1.33 (8H, brs, H-4-H-7). ${ }^{13} \mathrm{C}-\mathrm{NMR}\left(\mathrm{CD}_{3} \mathrm{OD}, 400 \mathrm{MHz}\right.$ ): 209.8 (C1), 163.5 (C-17 \& C-21), 144.1 (C-10), 136.9 (C-19), 129.5 (C-11 \& C15), 129.4 (C-12 \& C-14), 126.7 (C-13), 111.5 (C-16), 108.5 (C-18 \& C-20), 45.9 (C-2), 37.1 (C-9), 32.9 (C-8), 30.7 (C-4), 30.6 (C-5 \& C-6),<smiles>O=C(CCCCCCCCc1ccccc1)c1c(O)cccc1O</smiles>

(1)<smiles>O=C(CCCCCCCCc1ccc(O)c(O)c1)c1c(O)cccc1O</smiles><smiles>O=C(CCCCCCCCc1ccc(O)cc1)c1c(O)cccc1O</smiles>

(2)<smiles>O=C(CCCCCCCCc1ccc(O)cc1)c1c(O)cc(O)cc1O</smiles>

(3)

Figure 1. Structures of compounds 1-4. 
30.4 (C-7). 25.9 (C-3). LC/MS-IT-TOF: $349.1774\left([\mathrm{M}+\mathrm{Na}]^{+}\right.$; calc, $\mathrm{C}_{21} \mathrm{H}_{26} \mathrm{O}_{3} \mathrm{Na}$ 349.1774).

\section{Malabaricone B (2)}

Yellow amorphous powder. UV (MeOH): 341 (2.83), 270 (3.46), 206 (3.56). IR ( $\mathrm{NaCl}):$ 3584, 3339, 2927, 2854, 1708, 1596, 1514. ${ }^{1} \mathrm{H}-\mathrm{NMR}\left(\mathrm{CD}_{3} \mathrm{OD}, 400 \mathrm{MHz}\right): 7.17(1 \mathrm{H}, \mathrm{t}, J=8.0, \mathrm{H}-19), 6.96(2 \mathrm{H}, \mathrm{d}$, $J=8.0, \mathrm{H}-11$ \& H-15), $6.67(2 \mathrm{H}, \mathrm{d}, J=8.0, \mathrm{H}-12 \& \mathrm{H}-14), 6.33(2 \mathrm{H}$, $\mathrm{d}, J=8.0 \mathrm{~Hz}, \mathrm{H}-18 \& \mathrm{H}-20), 3.10(2 \mathrm{H}, \mathrm{t}, J=8.0, \mathrm{H}-2), 2.47(2 \mathrm{H}, \mathrm{t}, J$ $=8.0, \mathrm{H}-9), 1.66(2 \mathrm{H}, \mathrm{p}, J=8.0, \mathrm{H}-3), 1.56(2 \mathrm{H}, \mathrm{p}, J=8.0, \mathrm{H}-8), 1.31$ (8H, brs, H-4-H-7). ${ }^{13} \mathrm{C}-\mathrm{NMR}$ ( $\mathrm{CD}_{3} \mathrm{OD}, 400 \mathrm{MHz}$ ): 209.8 (C-1), 163.5 (C-17 \& C-21), 156.3 (C-13), 137.0 (C-19), 135.0 (C-10), 130.4 (C-11 \& C-15), 116.1 (C-12 \& C-14), 111.5 (C-16), 108.5 (C-18 \& C-20), 45.9 (C-2), 36.2 (C-9), 33.2 (C-8), 30.7 (C-4), 30.6 (C-5), 30.4 (C-6 \& C-7), 25.9 (C-3). LC/MS-IT-TOF: 365.1717 ([M + Na $]^{+}$; calc. $\left.\mathrm{C}_{21} \mathrm{H}_{26} \mathrm{O}_{4} \mathrm{Na} 365.1723\right)$.

\section{Malabaricone C (3)}

Yellow amorphous powder. UV (MeOH): 338 (2.80), 269 (3.36), 222 (3.50), 204 (3.70). IR ( $\mathrm{NaCl})$ : 3583, 3343, 2927, 2854, 1714, 1589, 1516. ${ }^{1} \mathrm{H}-\mathrm{NMR}\left(\mathrm{CD}_{3} \mathrm{OD}, 400 \mathrm{MHz}\right): 7.17(1 \mathrm{H}, \mathrm{t}, J=8.0, \mathrm{H}-19)$, $6.33(2 \mathrm{H}, \mathrm{d}, J=8.0, \mathrm{H}-18$ \& H-20), $6.65(1 \mathrm{H}, \mathrm{d}, J=8.0, \mathrm{H}-14), 6.60$ $(1 \mathrm{H}, \mathrm{d}, J=8.0, \mathrm{H}-11), 6.46(1 \mathrm{H}, \mathrm{dd}, J=8.0,1.8, \mathrm{H}-15), 3.10(2 \mathrm{H}, \mathrm{t}$, $J=8.0, \mathrm{H}-2), 2.43(2 \mathrm{H}, \mathrm{t}, J=8.0, \mathrm{H}-9), 1.65(2 \mathrm{H}, \mathrm{p}, J=8.0, \mathrm{H}-3), 1.53$ $(2 \mathrm{H}, \mathrm{brt}, \mathrm{J}=8.0, \mathrm{H}-8), 1.31(8 \mathrm{H}$, brs, $\mathrm{H}-4-\mathrm{H}-7) .{ }^{13} \mathrm{C}-\mathrm{NMR}\left(\mathrm{CD}_{3} \mathrm{OD}\right.$, $400 \mathrm{MHz}$ ): 209.8 (C-1), 163.5 (C-17 \& C-21), 146.1 (C-12), 144.1 (C-13), 137.0 (C-19), 136.0 (C-10), 120.8 (C-15), 116.6 (C-11), 116.3 (C-14), 111.5 (C-16), 108.5 (C-18 \& C-20), 45.9 (C-2), 36.4 (C-9), 33.1 (C-8), 30.7 (C-4), 30.5 (C-5 \& C-6), 30.4 (C-7), 25.9 (C-3). LC/MS-IT-TOF: 359.1860 ([M + H] $]^{+}$; calc. $\left.\mathrm{C}_{21} \mathrm{H}_{27} \mathrm{O}_{5} 359.1853\right)$.

\section{Malabaricone E (4)}

Yellow amorphous powder. UV (MeOH): 341 (2.83), 270 (3.46), 224 (3.67). IR ( $\mathrm{NaCl}): 3583,3272,2924,2853,1611,1515 .{ }^{1} \mathrm{H}-\mathrm{NMR}$ $\left(\mathrm{CD}_{3} \mathrm{OD}, 400 \mathrm{MHz}\right): 6.97(2 \mathrm{H}, \mathrm{d}, J=8.0, \mathrm{H}-11$ \& H-15), $6.67(2 \mathrm{H}, \mathrm{d}$, $J=8.0, \mathrm{H}-12 \& \mathrm{H}-14), 5.80(2 \mathrm{H}, \mathrm{s}, \mathrm{H}-18 \& \mathrm{H}-20), 3.02(2 \mathrm{H}, \mathrm{t}, J=8.0$ $\mathrm{Hz}, \mathrm{H}-2), 2.50(2 \mathrm{H}, \mathrm{t}, \mathrm{J}=8.0 \mathrm{~Hz}, \mathrm{H}-9), 1.64(2 \mathrm{H}, \mathrm{p}, J=8.0 \mathrm{~Hz}, \mathrm{H}-3)$, $1.55(2 \mathrm{H}, \mathrm{brt}, \mathrm{J}=8.0, \mathrm{H}-8), 1.33(8 \mathrm{H}, \mathrm{brs}, \mathrm{H}-4-\mathrm{H}-7) .{ }^{13} \mathrm{C}-\mathrm{NMR}\left(\mathrm{CD}_{3} \mathrm{OD}\right.$, $400 \mathrm{MHz}$ ): 207.6 (C-1), 166.5 (C-19), 165.9 (C-17 \& C-21), 156.3 (C-13), 135.0 (C-10), 130.3 (C-11 \& C-15), 116.1 (C-12 \& C-14), 105.0 (C-16), 95.8 (C-18 \& C-20), 44.9 (C-2), 36.2 (C-9), 33.2 (C-8), 30.9 (C-4), 30.6 (C-5 \& C-6), 30.4 (C-7), 26.3 (C-3). LC/MS-IT-TOF: $381.1675\left([\mathrm{M}+\mathrm{Na}]^{+}\right.$; calc. $\left.\mathrm{C}_{21} \mathrm{H}_{26} \mathrm{O}_{5} \mathrm{Na} 381.1672\right)$.

Expression and purification of the DENV-2 NS2B/NS3 protease The DENV-2 NS2B/NS3 protease was expressed and purified according to the method described by Hariono et al. (2019).

\section{DENV-2 NS2B/NS3 protease inhibition assay}

The in vitro protease inhibition assay was carried out using purified DENV-2 NS2B/NS3 protease as the enzyme and BocGly-Arg-Arg-MCA as the substrate according to the method previously described by our group (Salleh et al., 2019). The concentration of the enzyme and the substrate were $0.5 \mu \mathrm{M}$ and $10 \mathrm{mM}$, respectively in $200 \mathrm{mM}$ of Tris- $\mathrm{HCl}$ buffer $(\mathrm{pH} 8.5)$ while the concentration of the inhibitor was $200 \mu \mathrm{g} / \mathrm{mL}$. All of the tests were performed in quadruplicates. Firstly, the Tris- $\mathrm{HCl}$ buffer ( $\mathrm{pH} 8.5)$ was pipetted into the wells, followed by $1 \mu \mathrm{L}$ of the inhibitor and $3.1 \mu \mathrm{L}$ of the enzyme. Before adding the substrate, the enzyme and the inhibitor were incubated at $37^{\circ} \mathrm{C}$ for 10 minutes. After adding the substrate, the reaction mixture was incubated at $37^{\circ} \mathrm{C}$ for 60 minutes. All of the reactions were performed in 96 -well plates with a final volume of $100 \mu \mathrm{L}$ per well. Fluorescence was detected using a Promega Glomax Multi Detection System microplate reader with the excitation and emission wavelengths at 365 and $410-460 \mathrm{~nm}$, respectively. In order to determine the $I C_{50}$ values, the same protocol was used as described above with serial dilutions of the inhibitors with concentrations in the range of 1.5625 to $200 \mu \mathrm{g} / \mathrm{mL}$.

\section{Molecular docking}

Molecular docking was performed using AutoDock4.2 along with AutoDockTools (ADT) following the method described by Hariono et al. (2019) with some modifications (Hariono et al., 2019; Morris et al., 2009). The protein was prepared as described by Hariono et al. (2019) whereby the DENV-2 NS2B/ NS3pro model was built based on the DENV-2 complex cofactor-protease homology model using the crystal structure of the NS2B/NS3pro West Nile Virus (WNV) in complex with peptidic inhibitor and DENV-2 NS2B/NS3pro apoprotein as the template (Hariono et al., 2019; Wichapong et al., 2010). The structures of the compounds were constructed and energy minimization was performed using Hyperchem 8.0 (HyperChem (TM), Profesional 8.0, Hypercube, Inc). The minimized structures of the ligand and the protein were subjected to molecular docking using AutoDock4.2. Polar hydrogen and Kollman charges were added to the protein. For the ligands, the non-polar hydrogen atoms were merged and Gasteiger charges were assigned. A grid box with a dimension of $60 \times 60 \times 60$ and with a grid spacing of $0.375 \AA$ was positioned around the catalytic triad with the centre set at $x=21.517, y=43.428$ and $z=-1.743$. The dockings were carried out with the Lamarckian Genetics Algorithm (GA) search program applied to generate 250 runs. The conformation with the lowest binding energy in the most populated cluster was selected. The conformations from the docking experiments were analyzed and visualized using Discovery Studio 3.5 (www.accelrys.com).

\section{RESULTS AND DISCUSSION}

Preliminary screening of the ethyl acetate and methanol extracts of the fruits of $M$. cinnamomea at a concentration of $200 \mu \mathrm{g} / \mathrm{mL}$ proved that the extracts were potential inhibitors (96.69\% and $70.43 \%$, respectively) of the DENV-2 NS2B/NS3 protease. The ethyl acetate extract was subsequently subjected to repeated silica gel column chromatography, Sephadex LH-20 and preparative thin layer chromatography to yield four acylphenols, identified as malabaricone A (1), malabaricone $B(2)$, malabaricone $C(3)$ and malabaricone $E$ (4) (S1) upon comparison of their spectroscopic data with those previously reported by our group (Abdul Wahab et al., 2016; Sivasothy et al., 2016; Othman et al., 2019).

The initial DENV-2 NS2B/NS3 protease inhibitory activities of compounds $1-4$ were assayed at $200 \mu \mathrm{g} / \mathrm{mL}$ (Table 1). Since compounds 3 and 4 exhibited more that $70 \%$ inhibition towards the DENV-2 NS2B/NS3 protease, these compounds were further evaluated in order to determine

Table 1. Inhibition of the DENV-2 NS2B/NS3 protease by compounds 1-4 and Quercetin (standard)

\begin{tabular}{ccc}
\hline Compounds & $\begin{array}{c}\text { Percentage inhibition at } \\
200 \mu \mathrm{g} / \mathrm{mL}\end{array}$ & $\mathrm{IC}_{50}(\mu \mathrm{M})^{a}$ \\
\hline $\mathbf{1}$ & 31.92 & - \\
$\mathbf{2}$ & 67.70 & - \\
$\mathbf{3}$ & 98.54 & $27.33 \pm 5.45$ \\
$\mathbf{4}$ & 99.91 & $7.55 \pm 1.64$ \\
Quercetin (standard) & - & $10.48 \pm 2.14$ \\
\hline
\end{tabular}

a Data presented as Mean \pm SD $(n=4)$. 
their respective $I C_{50}$ values. The $I C_{50}$ values of compounds 3 and 4 along with the reference standard employed in this study are summarized in Table 1 . Compounds 3 (27.33 \pm 5.45 $\mu \mathrm{M})$ and $4(7.55 \pm 1.64 \mu \mathrm{M})$ both inhibited the DENV-2 NS2B/ NS3 protease with the latter being the stronger inhibitor among the two and around 1.5 times more potent than that of quercetin $(10.48 \pm 2.14 \mu \mathrm{M})$ itself.

Based on the molecular docking studies (Table 2, Figures 2 and 3 ) the inhibition of the DENV-2 NS2B/NS3 protease by compound 4 was probably due to the hydrogen bonding interactions between the following functional groups in compound 4 and the acid amino residues in the protease: hydroxyl group at C-17 and the oxygen atom of the carbonyl group (C-1) with Ser 135 of the catalytic triad, between the hydroxyl group at C-19 with Asp129 and Phe130 in the S1 pocket and between the hydroxyl group at C-13 with Ile86 in the S3 pocket. In addition, there was also a $\pi-\pi$ interaction between ring A with Tyr161 in the S1 pocket. As for compound 3, the hydroxyl groups at C-13 and C-17 formed hydrogen bonds with Gly151 while that of C-12 formed hydrogen bonds with not only Gly151 but with Tyr161 in the S1 pocket and Gly153 as well. The $\pi-\pi$ interaction between ring A with Tyr161 in the S1 pocket was also observed. The aforementioned interactions could have contributed to the activity of compound $\mathbf{3}$ (Table 2 , Figures 2 and 3 ).

Table 2. Binding interaction data for compounds 3 and 4 with amino acid residues of the NS2B/NS3 protease

\begin{tabular}{|c|c|c|c|c|c|}
\hline Ligand/Compound & $\begin{array}{l}\text { Binding Energy } \\
\text { (kcal/mol) }\end{array}$ & Residue & Type of Interaction & Distance $(\AA)$ & C10 \\
\hline \multirow[t]{6}{*}{ Malabaricone C (3) } & -5.47 & Gly153 & Hydrogen & 2.23 & Hydroxyl group $(\underline{\mathrm{O}} \mathrm{H})$ at $\mathrm{C}-12$ \\
\hline & & Gly151 & Hydrogen & 2.16 & Hydroxyl group $(\overline{\mathrm{O}} \underline{\mathrm{H}})$ at $\mathrm{C}-12$ \\
\hline & & & & 2.08 & Hydroxyl group $(\overline{\mathrm{OH}})$ at $\mathrm{C}-13$ \\
\hline & & & & 2.03 & Hydroxyl group $(\mathrm{O} \underline{\mathrm{H}})$ at $\mathrm{C}-17$ \\
\hline & & Tyr161 & Hydrogen & 2.39 & Hydroxyl group $(\mathrm{OH})$ at $\mathrm{C}-12$ \\
\hline & & & $\pi-\pi$ & - & Aromatic ring $A$ \\
\hline \multirow[t]{7}{*}{ Malabaricone E (4) } & -5.89 & Ser135 & Hydrogen & 2.02 & Carbonyl group at C-1 \\
\hline & & & Hydrogen & 1.80 & Hydroxyl group $(\mathrm{OH})$ at $\mathrm{C}-17$ \\
\hline & & Phe130 & Hydrogen & 2.40 & Hydroxyl group $(\underline{\mathrm{O}} \mathrm{H})$ at $\mathrm{C}-19$ \\
\hline & & & Hydrogen & 2.33 & Hydroxyl group $(\overline{\mathrm{O}} \underline{\mathrm{H}})$ at $\mathrm{C}-19$ \\
\hline & & Asp129 & Hydrogen & 1.96 & Hydroxyl group $(\mathrm{OH})$ at $\mathrm{C}-19$ \\
\hline & & Ile86 & Hydrogen & 2.18 & Hydroxyl group $(\mathrm{OH})$ at $\mathrm{C}-13$ \\
\hline & & Tyr161 & $\pi-\pi$ & - & Aromatic ring $A$ \\
\hline
\end{tabular}

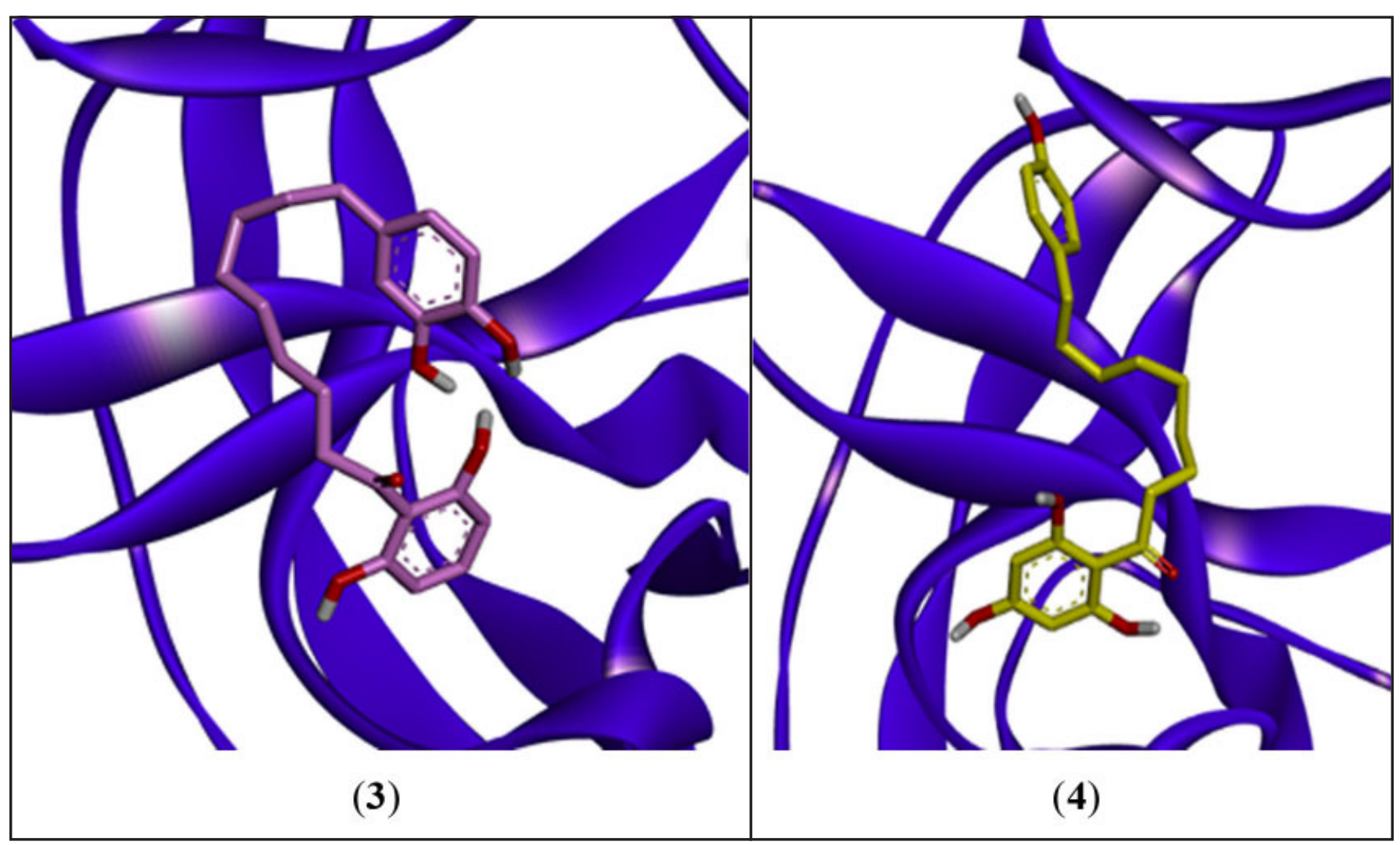

Figure 2. Visualization of malabaricone $C(3)$ and malabaricone $E(4)$ at the binding site of the NS2B/NS3 protease where the protein structures are represented by solid ribbon style. 


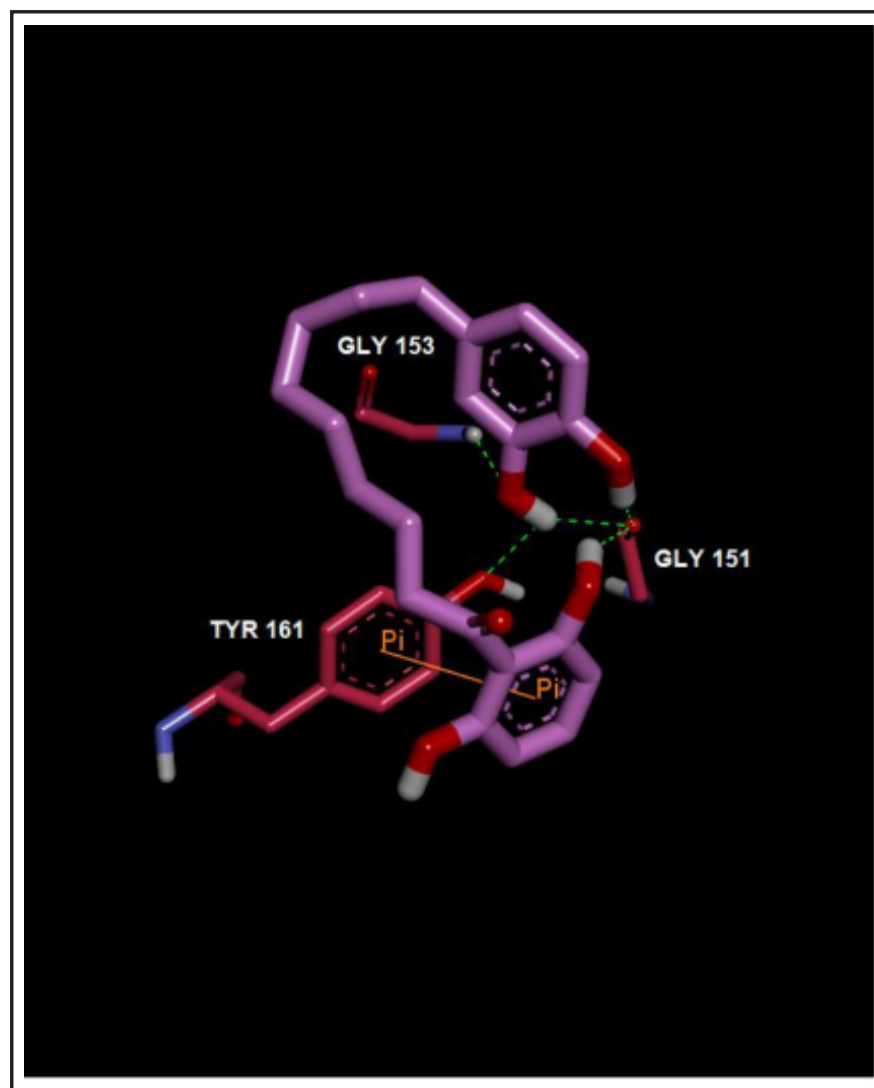

(3)

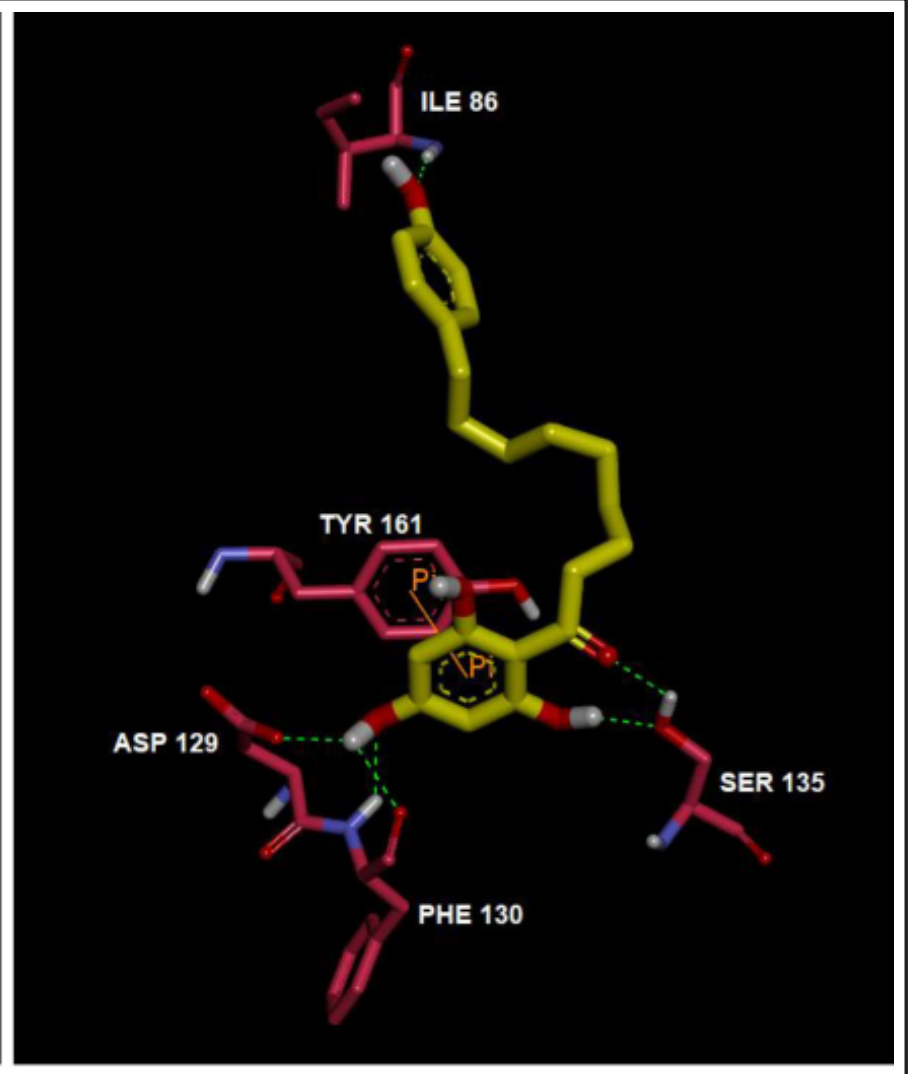

(4)

Figure 3. Simpliûed view of the binding interaction between malabaricone $C$ (3) and malabaricone $E$ (4) with the amino acid residues of the NS2B/NS3 protease. The hydrogen bonding of the ligands with the amino acid residues are shown in green dotted lines.

Upon comparison of the docking results obtained for both compounds, compound $\mathbf{4}$ was found to have a slightly lower binding energy $(-5.89 \mathrm{kcal} / \mathrm{mol})$ as compared to compound $3(-5.47 \mathrm{kcal} / \mathrm{mol})$ (Table 2$)$. The catalytic triad of the DENV-2 NS2B/NS3 protease is made up of the His51, Asp75 and Ser135 amino acid residues and only compound 4 was found to have a hydrogen bonding interaction with Ser135 (Hariono et al., 2019; Yin et al., 2006). Furthermore, the formation of a hydrogen bond with Asp129 was only observed for compound 4. Asp129 which is located at the bottom of the S1 pocket is an important amino acid residue as a previous study has revealed that it is the key interaction for the substrate recognition in the S1 pocket of the protein (Frecer \& Miertus, 2010). Hence, it would be reasonable to postulate that the above two interactions between compound 4 and the protease could be the reason behind the higher potency of compound $\mathbf{4}$ as compared to compound $\mathbf{3}$ towards the inhibition of the DENV-2 NS2B/NS3 protease.

\section{CONCLUSIONS}

Little is known about the potential usage of the genus Myristica in the treatment of dengue apart from a recent paper by Rosmalena et al. (2019). Rosmalena and her co-workers reported that the methanolic extract of $M$. fatua Houtt var. magnifica (Bedd.) Sinclair at a concentration of $20 \mu \mathrm{g} / \mathrm{mL}$ was found to actively inhibit (122.7\%) the DENV-2 NGC strain without any cytotoxic effect (Rosmalena et al., 2019; Cao et al., 2013; Herath and Padmasiri, 1999; Herath and Priyadarshani, 1996; Herath and Priyadarshini, 1997; Maia et al., 2008; Pham et al., 2002).
The potent inhibitory activity of the ethyl acetate extract towards the DENV-2 NS2B/NS3 protease in the current investigation has provided scientific evidence for the possible usage of the fruits of $M$. cinnamomea to treat dengue. Moreover, since malabaricone $C(3)$ which has been identified as a moderate inhibitor of the DENV-2 NS2B/NS3 protease is ubiquitous in many members of the genus Myristica, i.e $M$. fragrans, $M$. malabarica, $M$. fatua, $M$. crassa, $M$. gigantea, $M$. maingayi and $M$. maxima, therefore this makes the genus Myristica a promising and valuable source of dengue antivirals. On this basis, the in vitro, in vivo and in silico studies of compound $\mathbf{3}$ should be further investigated to facilitate the understanding of its mechanism of inhibition and to evaluate its effectiveness as an antiviral drug.

\section{ACKNOWLEDGEMENT}

The authors acknowledge the University of Malaya Research Grant RP001-2012A/B, UM.C/625/1/HIR/MOHE/SC/37 and the Centre National de la Recherche Scientifique (CNRS) grant (57-02-03-1007) which have made this work possible. The authors would also like to thank Dr. Shatrah Othman and her group from University of Malaya for providing the clone of the recombinant $p E T 14-N S 2 B / N S 3$. The results from this work are a collaborative effort between CNRS and University of Malaya (LIA-IFM-NatProLab).

\section{Conflict of Interest}

The authors declare that they have no conflict of interest. 


\section{REFERENCES}

Abd Kadir, S.L., Yaakob, H. \& Mohamed Zulkifli, R. (2013). Potential anti-dengue medicinal plants: a review. Journal of Natural Medicines 67: 677-689. https://doi.org/10.1007/ s11418-013-0767-y

Abdul Wahab, S.M., Sivasothy, Y., Liew, S.Y., Litaudon, M., Mohamad, J. \& Awang, K. (2016). Natural cholinesterase inhibitors from Myristica cinnamomea King. Bioorganic \& Medicinal Chemistry Letters 26: 3785-3792. https://doi.org/ 10.1016/j.bmcl.2016.05.046

Abubakr, M., Mandal, S.C. \& Banerjee, S. (2013). Natural compounds against flaviviral infections. Natural Product Communications 8: 1487-1492. https://doi.org/10.1177/ $1934578 \times 1300801039$

Aguilera-Pesantes, D., Robayo, L.E., Méndez, P.E., Mollocana, D., Marrero-Ponce, Y., Torres, F.J. \& Méndez, M.A. (2017). Discovering key residues of dengue virus NS2b-NS3protease: New binding sites for antiviral inhibitors design. Biochemical and Biophysical Research Communications 492: 631-642. https://doi.org/10.1016/j.bbrc.2017.03.107

Balasubramanian, A., Pilankatta, R., Teramoto, T., Sajith, A.M., Nwulia, E.A., Kulkarni, A. \& Padmanabhan, R. (2019). Inhibition of dengue virus by curcuminoids. Antiviral Research 162: 71-78. https://doi.org/10.1016/j.antiviral.2018. 12.002

de Sousa, L.R.F., Wu, H., Nebo, L., Fernandes, J.B., da Silva, M.F.d.G.F., Kiefer, W., Kanitz, M., Bodem, J., Diederich, W.E. \& Schirmeister, T. (2015). Flavonoids as noncompetitive inhibitors of Dengue virus NS2B-NS3 protease: Inhibition kinetics and docking studies. Bioorganic \& Medicinal Chemistry 23: 466-470. https://doi.org/10.1016/j.bmc.2014. 12.015

Dighe, S.N., Ekwudu, O.M., Dua, K., Chellappan, D.K., Katavic, P.L. \& Collet, T.A. (2019). Recent update on anti-dengue drug discovery. European Journal of Medicinal Chemistry 176: 431-455. https://doi.org/10.1016/j.ejmech.2019.05.010

Frecer, V. \& Miertus, S. (2010). Design, structure-based focusing and in silico screening of combinatorial library of peptidomimetic inhibitors of Dengue virus NS2B-NS3 protease. Journal of Computer-Aided Molecular Design 24: 195-212. https://doi.org/10.1007/s10822-010-9326-8

Hariono, M., Choi, S.B., Roslim, R.F., Nawi, M.S., Tan, M.L., Kamarulzaman, E.E., Mohamed, N., Yusof, R., Othman, S. \& Abd Rahman, N. (2019). Thioguanine-based DENV-2 NS2B/ NS3 protease inhibitors: Virtual screening, synthesis, biological evaluation and molecular modelling. PLOS ONE 14: e0210869. https://doi.org/10.1371/journal.pone.0210869

Mir, A., Ismatullah, H., Rauf, S. \& Niazi, U.H.K. (2016). Identification of bioflavonoid as fusion inhibitor of dengue virus using molecular docking approach. Informatics in Medicine Unlocked 3: 1-6. https://doi.org/10.1016/j.imu. 2016.06.001

Morris, G.M., Huey, R., Lindstrom, W., Sanner, M.F., Belew, R.K., Goodsell, D.S. \& Olson, A.J. (2009). AutoDock4 and AutoDockTools4: Automated docking with selective receptor flexibility. Journal of Computational Chemistry 30: 2785-2791. https://doi.org/10.1002/jcc.21256

Othman, M.A., Yuyama, K., Murai, Y., Igarashi, Y., Mikami, D., Sivasothy, Y., Awang, K. \& Monde, K. (2019). Malabaricone $C$ as natural sphingomyelin synthase inhibitor against diet-induced obesity and its lipid metabolism in mice. ACS Medicinal Chemistry Letters 10: 1154-1158. https:// doi.org/10.1021/acsmedchemlett.9b00171
Perera, S.D., Jayawardena, U.A. \& Jayasinghe, C.D. (2018). Potential use of Euphorbia hirta for dengue: A systematic review of scientific evidence. Journal of Tropical Medicine 2018. https://doi.org/10.1155/2018/2048530

Rosmalena, R., Elya, B., Dewi, B.E., Fithriyah, F., Desti, H., Angelina, M., Hanafi, M., Lotulung, P.D. \& Prasasty, V.D. (2019). The antiviral effect of Indonesian medicinal plant extracts against dengue virus in vitro and in silico. Pathogens 8: 85. https://doi.org/10.3390/pathogens 8020085

Rozera, R., Verma, S., Kumar, R., Haque, A. \& Attri, A. (2019). Herbal remedies, vaccines and drugs for dengue fever: Emerging prevention and treatment strategies. Asian Pacific Journal of Tropical Medicine 12: 147-152. https:// doi.org/10.4103/1995-7645.257113

Salleh, H.M., Chong, S.-L., Othman, R., Hazni, H., Ahmad, K., Mohd Yusof, M.Y.Z., Fauzi, N.W., Wahab, H.A., Liew, S.Y. \& Awang, K. (2019). Dengue protease inhibition activity of selected Malaysian medicinal herbs. Tropical Biomedicine 36: 357-366.

Singh, P.K. \& Rawat, P. (2017). Evolving herbal formulations in management of dengue fever. Journal of Ayurveda and Integrative Medicine 8: 207-210. https://doi.org/10.1016/ j.jaim.2017.06.005

Sivasothy, Y., Krishnan, T., Chan, K.G., Abdul Wahab, S.M., Othman, M.A., Litaudon, M. \& Awang, K. (2016). Quorum sensing inhibitory activity of Giganteone A from Myristica cinnamomea King against Escherichia coli biosensors. Molecules (Basel, Switzerland) 21: 391. https://doi.org/ 10.3390/molecules21030391

Takagi, Y., Matsui, K., Nobori, H., Maeda, H., Sato, A., Kurosu, T., Orba, Y., Sawa, H., Hattori, K. \& Higashino, K. (2017). Discovery of novel cyclic peptide inhibitors of dengue virus NS2B-NS3 protease with antiviral activity. Bioorganic \& Medicinal Chemistry Letters 27: 3586-3590. https://doi.org/ 10.1016/j.bmcl.2017.05.027

Teixeira, R.R., Pereira, W.L., Oliveira, A.F.C.D.S., da Silva, A.M., de Oliveira, A.S., da Silva, M.L., da Silva, C.C. \& de Paula, S.O. (2014). Natural products as source of potential dengue antivirals. Molecules (Basel, Switzerland) 19: 8151-8176. https://doi.org/10.3390/molecules19068151

Timiri, A.K., Sinha, B.N. \& Jayaprakash, V. (2016). Progress and prospects on DENV protease inhibitors. European Journal of Medicinal Chemistry 117: 125-143. https://doi.org/10.1016/ j.ejmech.2016.04.008

Weng, Z., Shao, X., Graf, D., Wang, C., Klein, C.D., Wang, J. \& Zhou, G.C. (2017). Identification of fused bicyclic derivatives of pyrrolidine and imidazolidinone as dengue virus-2 NS2B-NS3 protease inhibitors. European Journal of Medicinal Chemistry 125: 751-759. https://doi.org/10.1016/j.ejmech. 2016.09.063

Wichapong, K., Pianwanit, S., Sippl, W. \& Kokpol, S. (2010). Homology modeling and molecular dynamics simulations of dengue virus NS2B/NS3 protease: insight into molecular interaction. Journal of Molecular Recognition 23: 283-300. https://doi.org/10.1002/jmr.977

Yin, Z., Patel, S.J., Wang, W.-L., Chan, W.-L., Ranga Rao, K.R., Wang, G., Ngew, X., Patel, V., Beer, D. \& Knox, J.E. (2006). Peptide inhibitors of dengue virus NS3 protease. Part 2: SAR study of tetrapeptide aldehyde inhibitors. Bioorganic \& Medicinal Chemistry Letters 16: 40-43. https://doi.org/ 10.1016/j.bmcl.2005.09.049 